\title{
BIOLOGICAL AGENTS AND INSECTICIDES TO CONTROL BUNCH MOTH, Tirathaba rufivena IN OIL PALM ESTATES IN SARAWAK, MALAYSIA
}

\author{
SAHARUL ABILLAH MOHAMAD*; ZULKEFLI MASIJAN*; RAMLE MOSLIM*; MOHAMAD ROSMAN \\ SULAIMAN*; SU CHONG MING**; SIAW TING CHUAN; NORMAN KAMARUDIN*; SITI RAMLAH \\ AHMAD ALI* and SITI NURULHIDAYAH AHMAD*
}

\begin{abstract}
The effectiveness of biological products and insecticides in controlling the infestation of Tirathaba rufivena in oil palm estates in Sarawak, Malaysia was evaluated. The study was conducted in two sites from November 2014 to May 2015 on oil palm aged 4 and 5 years. The treatments tested in both sites were commercially available and MPOB-produced Bacillus thuringiensis product, Metarhizium anisopliae, chlorantraniliprole and cypermethrin. The study showed that the first and second instar larvae of bunch moth were found mostly on male inflorescences, and the third and fourth instar larvae were found on female inflorescences and developing bunches. All treatments were effective in reducing the larval population of bunch moth as early as seven days after the first treatment (DAFT). However, the larval population at plots treated with B. thuringiensis recorded inconsistent results. In Site 1, it was observed that only the commercial B. thuringiensis was able to control the larval population of bunch moth up to 34 DAFT. Whereas in Site 2, both B. thuringiensis and Metarhizium anisopliae products gave control as good as chemicals up to 49 DAFT. Chlorantraniliprole application gave rapid reduction and was able to reduce and maintain low population of bunch moth up to 59 days after the last spraying. A more comprehensive study is needed to be carried out by incorporating other control measures such as mass trapping of adults and spraying of larvae using biological and chemical products in the coastal peat areas.
\end{abstract}

Keywords: oil palm, bunch moth, Tirathaba rufivena, cypermethrin, chlorantraniliprole, Bacillus thuringiensis, Metarhizium anisopliae, peat.

Date received: 29 December 2016; Sent for revision: 3 January 2017; Received in final form: 27 February 2017; Accepted: 4 July 2017.

\section{INTRODUCTION}

Bunch moth is also known as 'inflorescence moth' or 'fruit moth' of palm (Basri and Norman, 2000). Out of 30 species reported, one species, Tirathaba rufivena is found infesting oil palm in Malaysia

Malaysian Palm Oil Board, 6 Persiaran Institusi,

Bandar Baru Bangi, 43000 Kajang, Selangor, Malaysia.

E-mail: saharul.abillah@mpob.gov.my

** Research and Development Department, Lambir Research Centre, Sarawak Oil Palms Berhad (SOPB), 98007 Miri, Sarawak, Malaysia.

\# Research and Development Department,

Ta Ann Plantation Sdn Bhd,

96000 Sibu, Sarawak, Malaysia. and Indonesia (Khoo et al., 1991; Susanto et al., 2011). This species is easily recognised based on the forewing colouration of the adult moth, which is greenish or brown, with thin red stripes for female and silvery gray for male (Figure 1) (Khoo et al., 1991; Basri and Norman, 2000; Moore, 2001). According to Yaakop et al. (2015), the species of Tirathaba consists of five larval stages, where each stage is differentiated by size and body length. The larvae are the destructive stage, damaging both male and female inflorescences, and developing fruitlets of young bunches (Lim, 2012). On developing bunches, the larvae feed and scrape on the fruitlets, later boring holes into the mesocarp up to the kernel. High infestation can greatly reduce the 

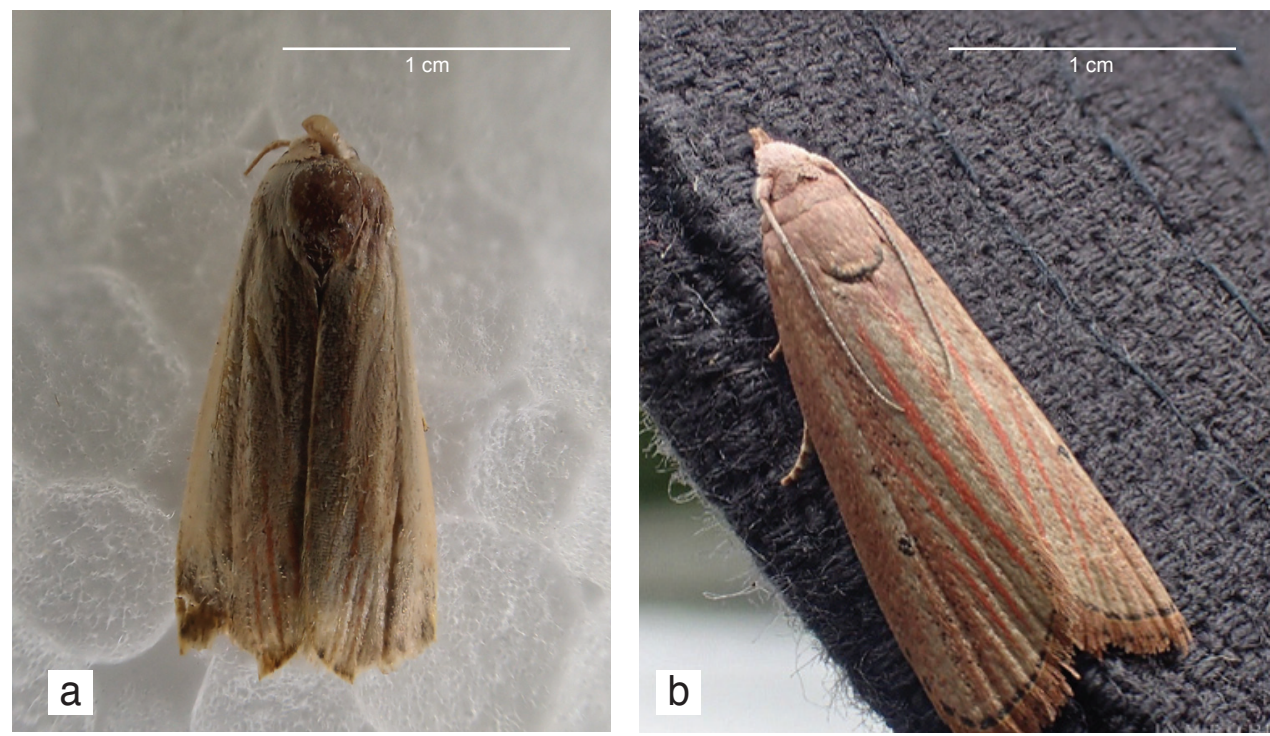

Figure 1. Dorsal view adults of Tirathaba rufivena. a) Male b) female collected in Sarawak, Malaysia.

quality and weight of the fruit bunch and may cause malformed and premature bunch abortion (Alouw et al., 2005). It was also reported that the areas which experienced heavy infestation have recorded lower number of bunches per palm and high number of rotten bunches (Idrus et al., 2016). Infestation is characterised by the presence of long tube of silk and frass in the bunch, which are reddish when fresh and brownish-black when old (Lim, 2012).

T. rufivena is becoming an important insect pest on oil palm planted on peat in Sarawak (Lim, 2012; Zulkefli et al., 2012). Outbreaks of this pest have been reported throughout oil palm plantations on peat, with most badly affected areas located on coastal peat in Mukah, Sibu and Miri (Zulkefli et al., 2015). A survey in 2016 showed that the estimated affected areas were more than 47700 ha (MPOB, 2016). The increasing population of bunch moth is associated to the abundance of food sources such as unharvested ripe bunches, the presence of breeding sites such as inflorescences and scarcity of natural enemies (Susanto et al., 2011).

Planters mainly rely on insecticides, particularly cypermethrin, to control the bunch moth (Lim, 2012). This is due to fast action and low cost as compared to B. thuringiensis (Basri et al., 1991). However, the chemical is adversely affecting the population of oil palm pollinating weevil, Elaeidobius kamerunicus and its rate of degradation is slow when applied on peat (Ismail et al., 2012). Efforts to control this pest using biological agents such as the parasitoid, Argyrophylax basifulva and nematode, Steinernema feltiae have been unsuccessful (Godfray, 1985; Zelazny, 1985). Therefore, it is urgently needed to find sustainable measures to control the bunch moth $T$. rufivena, preferably by enhancing the use of microbial agents, and extending the interval of insecticide application.
Thus, the main aim of this study is to evaluate the effectiveness of microbial agents and chemical insecticides to control the population of T. rufivena in oil palm planted on peat.

\section{MATERIALS AND METHODS}

\section{Experimental Site and Design}

The study was conducted in two sites namely Site 1 and Site 2. In Site 1, the experiment was conducted in Block 305, Kuala Igan Estate, Igan, Sarawak, Malaysia from November 2014 to February 2015. In Site 2, the study was carried out in Block K39, Tinbarap 7/9 Estate, Bakong, Sarawak from March 2015 to May 2015. In both experimental sites, the experiment was carried out using a randomised complete block design with four replications, covering 20 sub-plots. The planting designs in both sites were different. In Site 1, each sub-plot comprised of 68 palm with the arrangement of four inter-row palms $x 17$ in between palm, giving an estimate of 1360 treated palms. Meanwhile, in Site 2, each sub-plot comprised of 48 palms with the arrangement of four inter-row palms $x 12$ in between palms, giving a total of 960 treated palms. The age of palm was four-year old in Site 1 and fiveyear old in Site 2. No guard palms were used in the study as the spraying drift of treatments moving to neighbouring palms was considered negligible.

\section{Treatment and Application}

In each experimental site, five treatments including untreated control were tested. The active ingredient and application rates for each treatment in Sites 1 and 2 are summarised in Tables 1 and 2. The 
TABLE 1. ACTIVE INGREDIENTS AND APPLICATION RATES OF PRODUCTS TESTED IN SITE 1

\begin{tabular}{|c|c|c|c|}
\hline No. & Active ingredient & $\begin{array}{c}\text { Concentration } \\
\text { a.i }\end{array}$ & $\begin{array}{l}\text { Application rate/ } \\
16 \text { litres water }(\mathrm{ml})\end{array}$ \\
\hline 1. & Control & & \\
\hline 2 & Cypermethrin & $5.5 \%$ & 30 \\
\hline 3. & Chlorantraniliprole & $5.0 \%$ & 8 \\
\hline 4. & $\begin{array}{l}\text { B. thuringiensis ss } \\
\text { kurstaki } \\
\text { (commercial) }\end{array}$ & $17600 \mathrm{IU} \mathrm{mg}^{-1}$ & 24 \\
\hline 5. & $\begin{array}{l}\text { Bacillus } \\
\text { thuringiensis } \\
\text { (MPOB- Ecobac 1) }\end{array}$ & $16000 \mathrm{IU} \mathrm{mg}^{-1}$ & 640 \\
\hline
\end{tabular}

TABLE 2. ACTIVE INGREDIENTS AND APPLICATION RATES OF PRODUCTS TESTED IN SITE 2

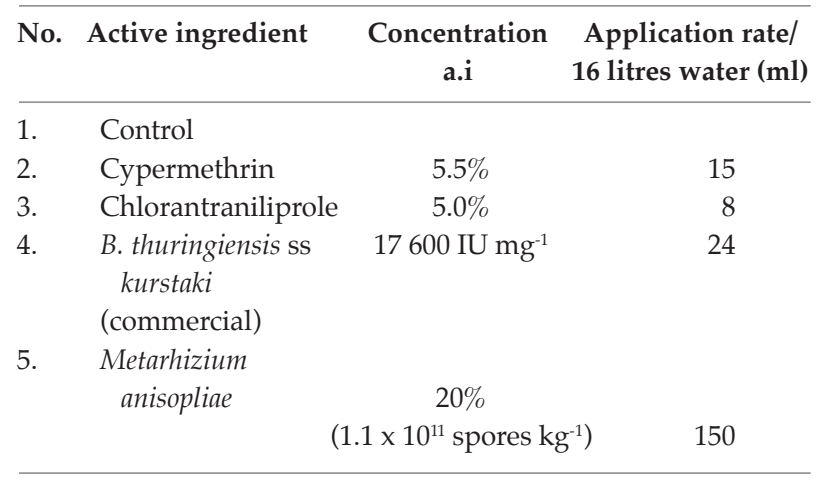

treatments selected for trial in Site 1 are commercially available cypermethrin 5.5\%, chlorantraniliprole $5.0 \%$, Bacillus thuringiensis ss kurstaki $17600 \mathrm{IU} \mathrm{mg}^{-1}$ and MPOB-produced Bacillus thuringiensis (MPOBEcobac 1). Meanwhile, in Site 2, treatments involved were commercially available cypermethrin 5.5\%, chlorantraniliprole 5.0\%, Bacillus thuringiensis ss kurstaki $17600 \mathrm{IU} \mathrm{mg}^{-1}$ and Metarhizium anisopliae $\left(1.1 \times 10^{11}\right.$ spores $\left.\mathrm{kg}^{-1}\right)$. After considering the field performances of each treatment in Site 1 , it was decided to replace MPOB-produced B. thuringiensis with different biological agent, a commercially available $M$. anisopliae for testing in Site 2. The tested product for each treatment was uniformly applied using a 16 litres manual knapsack sprayer with a cone-shaped nozzle. Prior to application, calibration was conducted to ensure uniform and accurate rate of treatments. Based on the calibration, 1 litre of product solution was required to achieve satisfactory penetration into the palm crown region. Every palm was subjected to four rounds of treatment application at 14-day intervals at both study sites. Spraying was directed onto all post-anthesising male and female inflorescences and fruit bunches in the treated palms. Spraying directed onto anthesising male inflorescences was avoided to minimise the mortality rate of oil palm pollinating weevil, Elaeidobius kamerunicus. To improve adherence and deposition of droplets, 10 $\mathrm{ml}$ of the sticking agent, Nufarm Bond ${ }^{\circledR}$ was added into the sprayer tank before application.

\section{Data Recording}

At both sites, pre-census to estimate the population of bunch moth and palm damage severity was conducted a week prior to the treatments. The randomisation of experimental plots was done based on this pre-census data. Data on numbers of live larvae and developmental stages of bunch moth was recorded from a total of five samples for Site 1 and six samples for Site 2, consisting of one postanthesis male inflorescences in Site 1 and two postanthesis male inflorescences in Site 2, two each of developing bunches and female inflorescences in both sites. The samples in Site 1 had to be reduced due to lack of suitable post-anthesis male inflorescences. Sampling was conducted at 7, 21, 34 and 84 days after first treatment (DAFT) at Site 1 and 7, 21, 35 and 49 DAFT at Site 2. Based on the result from Site 1 , it was felt that the long gap between 34 and 84 days after treatment was too long and the gap has allowed the larval population to re-establish, which also indicates the short efficacy period of the treatments. Therefore, was decided to shorten the sampling period gap, which will better reflect the field performances of the treatments selected. Each sample was chopped to individual spikelet before the number of live larvae or pupae were counted and sorted according to developmental stages.

\section{Data Analysis}

The number of live developmental stages of bunch moth at each data recording was analysed using one-way analysis of variance. The differences between means for each data were separated using Duncan's Multiple Range Test at $\mathrm{P}=0.05$.

\section{RESULT AND DISCUSSION}

\section{Distribution of Population and Developmental Stages}

The distribution of bunch moth population before treatment at both study sites was estimated. Infestation of bunch moth in each experimental block was assessed from 20 samples of male inflorescences, and 40 samples of each female inflorescence and developing bunches in Site 1. The lesser number of male inflorescences samples was due to low number of male inflorescences available in the experimental site. Meanwhile, in Site 2, the severity of infestation in the experimental block was assessed from 40 samples of male inflorescences, female inflorescence and developing bunches. In Site 
1, data recorded from pre-treatment census showed that the experimental area has high infestation of live larvae on male inflorescences as compared to female inflorescences and developing bunches (Table 3). In Site 1, the early larval instars, which were abundant in male inflorescences, outnumbered the later stage larvae, which can be mostly found in female inflorescences and developing bunches. However, the number of live larvae collected in Site 2 was more evenly distributed across all types of samples (Table 4). This indicates that in Site 2, the number of early and later instar larvae did not differ significantly.

The distribution of developmental stages of live larvae on each type of samples was also determined (Figures 2 and 3). In Site 1, it was observed that most of the early instar larvae (L1 and L2) of bunch moth were found on male inflorescences, and the later instar larvae (L3 and L4) were found on female inflorescences and developing bunches. Whereas in Site 2, the early larval instar (L1 and L2) can be found in all types of samples. It was also observed that in Site 2, low number of late larval instar (L3 and L4) were found during the pre-treatment census. Although reasons on why high number of early instar were found on male inflorescence are still unknown, it is possibly because the pest prefers to lay eggs and starts to breed on post-anthesis male inflorescences (PAMI). This observation supports the earlier findings by Wood and $\mathrm{Ng}$ (1974), who reported that the early stage of bunch moth was abundant on male inflorescences.

TABLE 3. DISTRIBUTION OF LIVE LARVAL POPULATION OF BUNCH MOTH RECORDED ON MALE INFLORESCENCES, FEMALE INFLORESCENCES AND DEVELOPING BUNCHES IN SITE 1

\begin{tabular}{|c|c|c|c|c|c|c|c|c|}
\hline \multirow[t]{2}{*}{$\begin{array}{l}\text { Type of } \\
\text { sample }\end{array}$} & \multicolumn{8}{|c|}{$\begin{array}{c}\text { Number of larvae per sample in } \\
\text { the experimental block }\end{array}$} \\
\hline & $\mathbf{n}$ & Block 1 & $\mathbf{n}$ & Block 2 & $\mathbf{n}$ & Block 3 & $\mathbf{n}$ & Block 4 \\
\hline Male inflorescence & 5 & $35.2 \pm 11.12$ & 5 & $30 \pm 13.43$ & 5 & $17.8 \pm 8.89$ & 5 & $78.4 \pm 43.51$ \\
\hline Female inflorescence & 10 & $9.5 \pm 3.16$ & 10 & $10.9 \pm 4.88$ & 10 & $10.2 \pm 3.05$ & 10 & $17.6 \pm 5.77$ \\
\hline Developing bunch & 10 & $15.6 \pm 5.26$ & 10 & $17 \pm 2.44$ & 10 & $10 \pm 3.37$ & 10 & $14.7 \pm 4.00$ \\
\hline
\end{tabular}

TABLE 4. DISTRIBUTION OF LIVE LARVAL POPULATION OF BUNCH MOTH RECORDED ON MALE INFLORESCENCES, FEMALE INFLORESCENCES AND DEVELOPING BUNCHES IN SITE 2

\begin{tabular}{|c|c|c|c|c|c|c|c|c|}
\hline \multirow[t]{2}{*}{$\begin{array}{l}\text { Type of } \\
\text { sample }\end{array}$} & \multicolumn{8}{|c|}{$\begin{array}{c}\text { Number of larvae per sample in } \\
\text { the experimental block }\end{array}$} \\
\hline & $\mathbf{n}$ & Block 1 & $\mathbf{n}$ & Block 2 & $\mathbf{n}$ & Block 3 & $\mathbf{n}$ & Block 4 \\
\hline Male inflorescence & 10 & $32.7 \pm 14.37$ & 10 & $7.30 \pm 3.54$ & 10 & $6.6 \pm 1.48$ & 10 & $2.30 \pm 1.55$ \\
\hline Female inflorescence & 10 & $18.4 \pm 5.70$ & 10 & $14.4 \pm 3.60$ & 10 & $11.9 \pm 2.89$ & 10 & $6.6 \pm 0.99$ \\
\hline Developing bunch & 10 & $10.1 \pm 2.14$ & 10 & $13.5 \pm 3.26$ & 10 & $7.7 \pm 1.89$ & 10 & $2.40 \pm 1.02$ \\
\hline
\end{tabular}

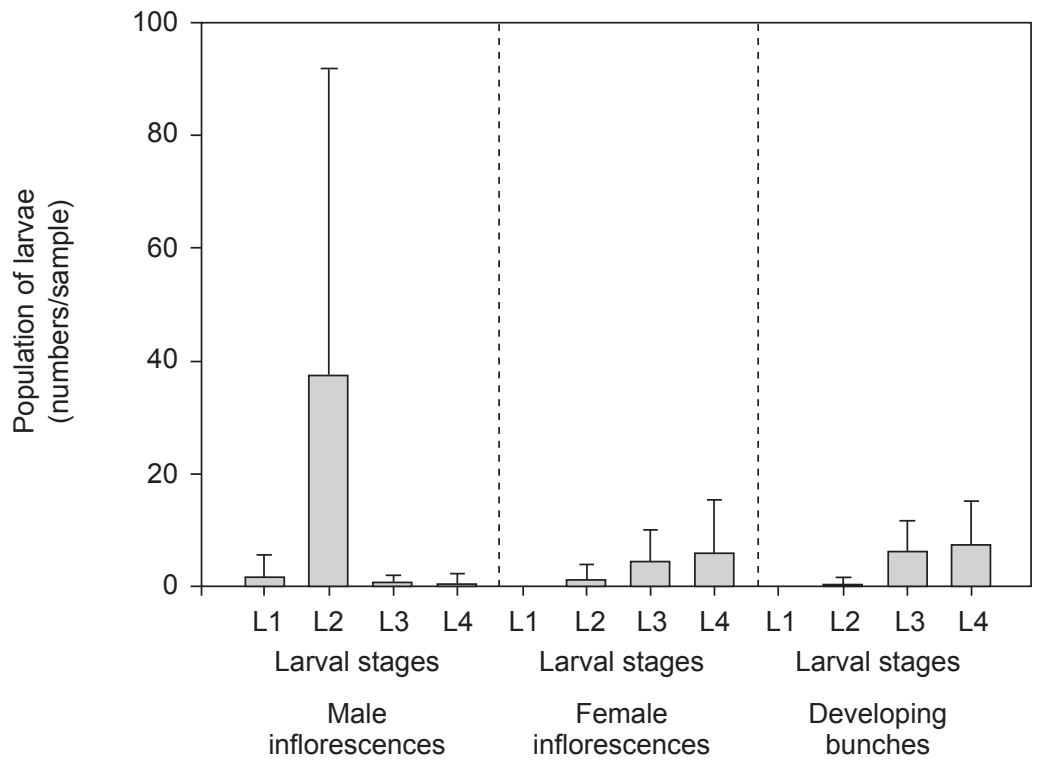

Figure 2. Distribution of developmental stages of bunch moth larvae sampled from male and female inflorescences and developing bunches in Site 1. 


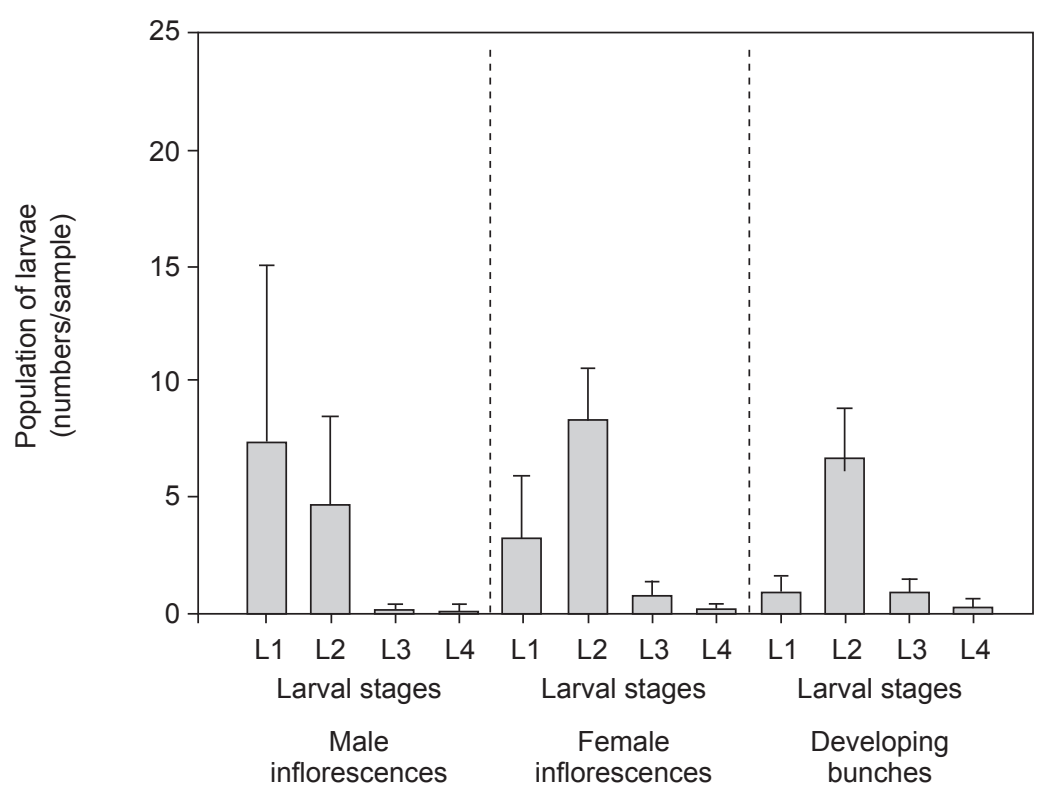

Figure 3. Distribution of developmental stages of bunch moth larvae sampled from male and female inflorescences and developing bunches in Site 2.

\section{Impact of Treatments on Larval Population}

In Site 1, the pre-census data showed that the population of live larvae per sample (LPS) in each treatment plot was not significantly different $(P>0.05)$. The number of live larvae in the experimental plots for control, cypermethrin, chlorantraniliprole, MPOB-Bt and commercial Bt (Bt-COM) was 21.7, 21.3, 14, 47.8 and 19.4 LPS, respectively. At $7 \mathrm{DAFT}$, the number of live larvae in all treatments were reduced and significantly lower $(\mathrm{P}<0.05)$ than control, except for MPOB-Bt (Figure 4). Among the treatments, it was observed that chlorantraniliprole caused a rapid reduction on the larval population to the lowest level of 1.4 LPS.

At 21 DAFT, further reduction on the larval population in all treatment plots was recorded. The populations of larvae in all treatment were significantly lower than control. At 34 DAFT, application of cypermethrin and chlorantraniliprole has completely controlled the bunch moth. None of the bunch moth larvae was found on the samples collected from plots treated by both products. However, the infestation of live larvae of bunch moth in all treatment plots increased at 84 DAFT (Figure 4). At this period, chlorantraniliprole was the only treatment that still gave significantly good control to bunch moth larvae, manifesting the longer effects of the insecticide on the pest populations compared to other treatments. It was also recorded that the infestation levels in blocks treated with commercial $B t$ was higher than those in control plots, suggesting rapidly waning effects of commercial $B t$ on the population of bunch moth larvae. This also shows that another round of commercial Bt application is required in the period between 34 and 84 DAFT to prevent rapid population re-emergence. Study in
Site 1 showed that every treatment, except MPOB$B t$ was able to give satisfactory control over the bunch moth population up to 34 DAFT, before re-emergence of the population occurred. The differences in the efficacy of both $B t$ products is possibly attributed to the type of strains and $B t$ toxin mixture in each product. MPOB-Bt is a product that was developed using a local isolate, known as MPOB B. thuringiensis 1, specifically produced for the Integrated Pest Management (IPM) programme to control bagworm (Metisa plana) outbreak (Siti Ramlah et al., 2012). The product specificity may cause it to be ineffective in controlling the population of bunch moth larvae. Meanwhile, COM-Bt contains proprietary, high yielding $B$. thuringiensis subspecies kurstaki and blended with various $B t$ protein toxins, which maximise its efficacy against lepidopteran pests (Valent Biosciences, 2014).

In Site 2, the effects of treatments in reducing the population of bunch moth $T$. rufivena are shown in Figure 5. Pre-census showed no significant differences on bunch moth population between blocks selected for the study. At seven DAFT, all treatments, except for plots treated with $B$. thuringiensis were able to significantly reduce $(\mathrm{P}<0.05)$ the population of T. rufivena compared to control. The population of bunch moth in all treatment plots was then maintained significantly lower $(\mathrm{P}<0.05)$ than control until the end of the experiment at 49 DAFT. At 21 DAFT, the lowest population of 0.50 LPS was recorded in blocks treated with chlorantraniliprole. At 49 DAFT, blocks treated with cypermethrin recorded the lowest bunch moth larvae population of 0.33 LPS, which was not significantly different from other treatments, including both microbial agents of commercial $B t$ and $M$. anisopliae. Blocks treated with commercial $B t$ recorded bunch 
a) 7 Days after first treatment

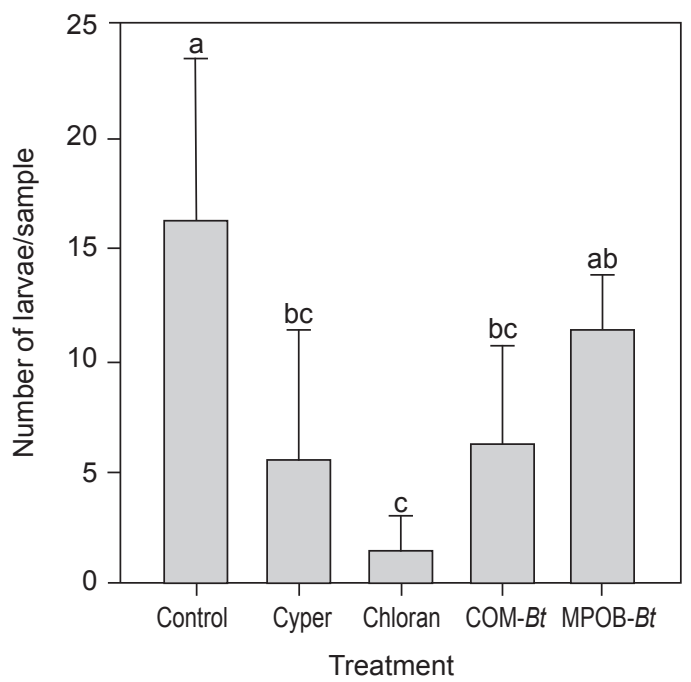

c) 34 Days after first treatment

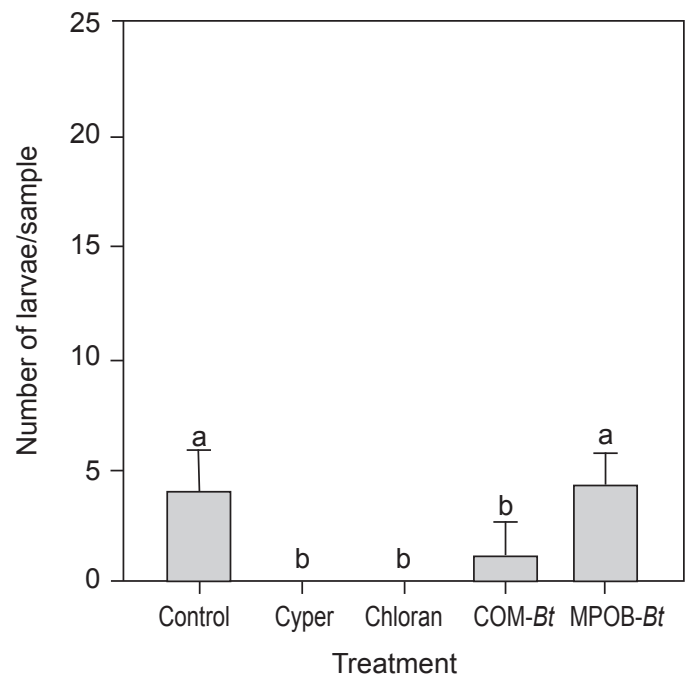

b) 21 Days after first treatment

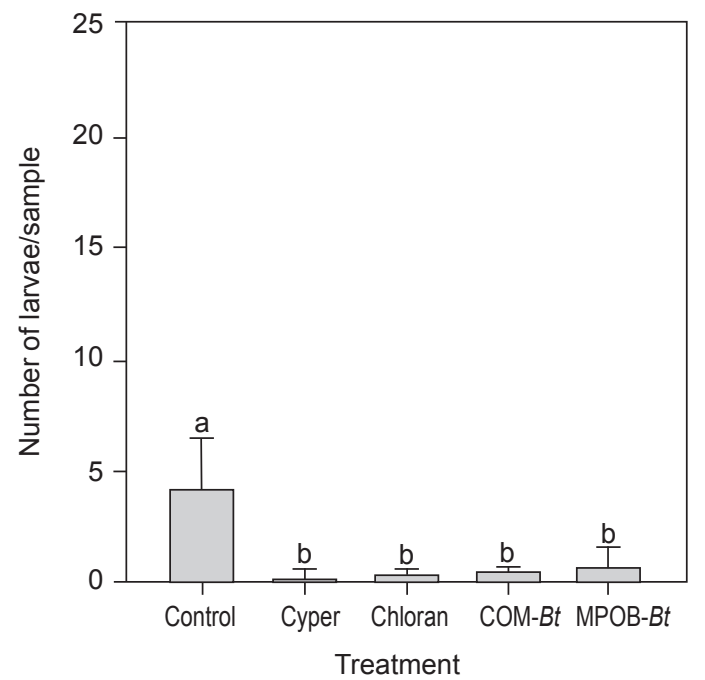

d) 84 Days after first treatment

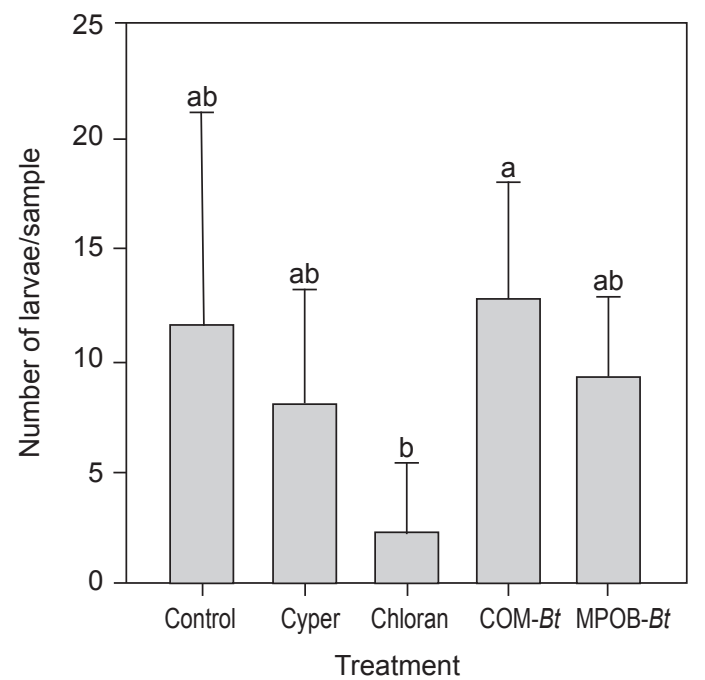

Figure 4. The effectiveness of treatments to control bunch moth, Tirathaba rufivena after 7, 21, 34 and 84 days after the first treatment in Site 1. Bars in each graph with the same letters were not significantly different by DMRT at $P=0.05$.

Note:

Cyper : Cypermethrin.

Chloran : Chlorantraniliprole.

COM-Bt : Commercial B. thuringiensis.

MPOB-Bt: MPOB-produced B. thuringiensis product (Ecobac 1).

moth larvae population of 0.96 LPS. This finding proves that commercially-available $B t$ is as good as cypermethrin in controlling bunch moth larvae population and therefore is recommended due to its non-injurious effect on the pollinating weevil, E. kamerunicus (Lopez et al., 2016; Najib et al., 2009; Ramle et al., 2006) and other beneficial insects (Salama and Zaki, 1984; Kumar et al., 2014).

In Site 2, all four treatments were able to successfully control the bunch moth population. At 49 DAFT, application of all treatments has significantly reduced $(\mathrm{P}<0.05)$ the population of bunch moth to the lowest level. However, application of biological agents such as $B$. thuringensis and $M$. anisopliae was more preferable as the products have less adverse effects on beneficial and nontarget organisms (Najib et al., 2009; Ramle et al., 2006; Salama and Zaki, 1984; Kumar et al., 2014). Results from this study found that both $B$. thuringensis and $M$. anisopliae can suppress the population of bunch moth larvae to below the threshold level of 5 LPS until 49 DAFT.

Research work on evaluation of products to control bunch moth has been carried out by various 
a) 7 Days after first treatment

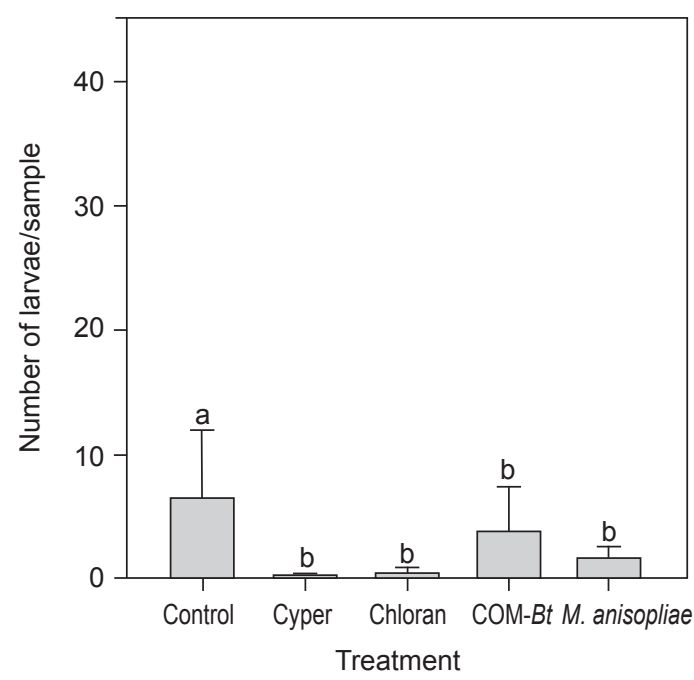

c) 35 Days after first treatment

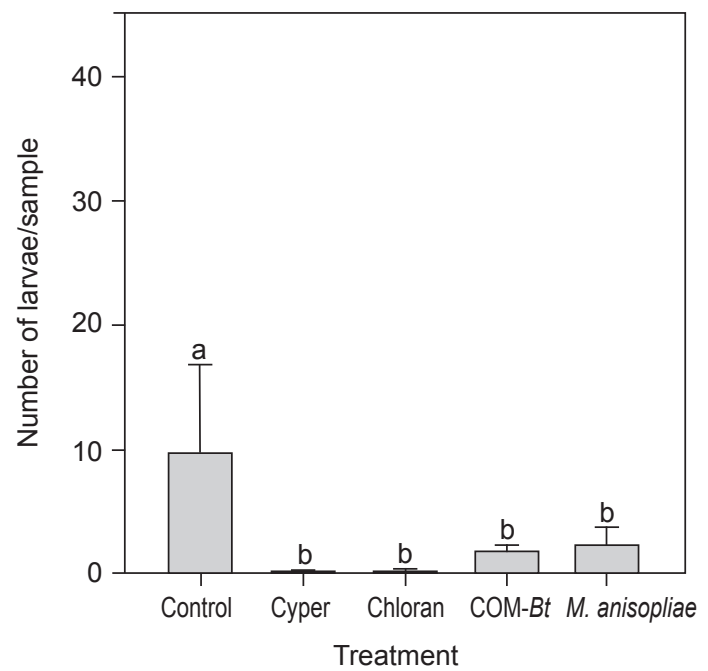

b) 21 Days after first treatment

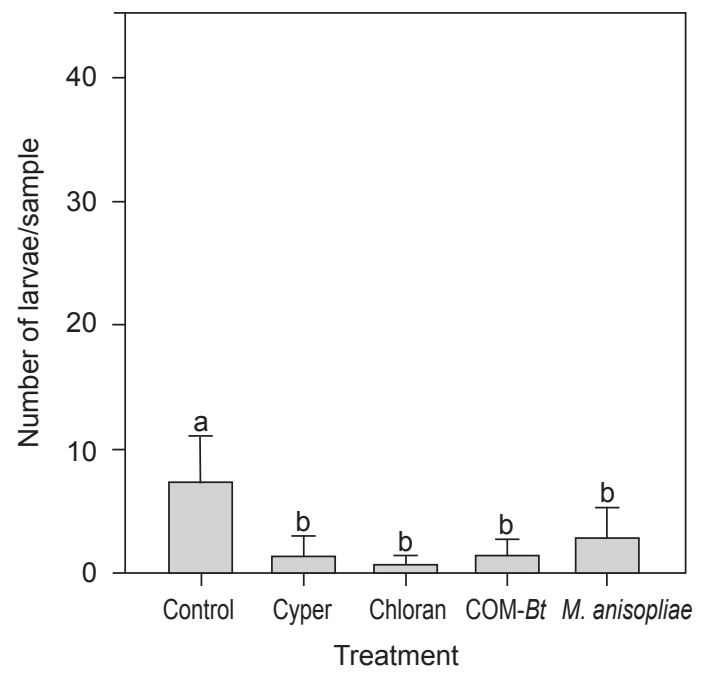

d) 49 Days after first treatment

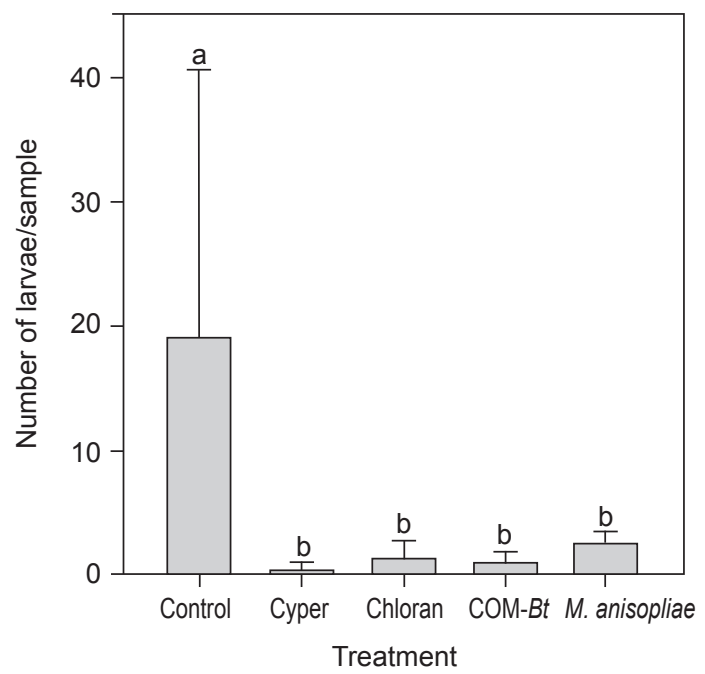

Figure 5. The effectiveness of treatments to control bunch moth, Tirathaba rufivena after 7, 21, 35 and 49 days after the first treatment in Site 2. Bars in each graph with the same letters were not significantly different by DMRT at $P=0.05$.

Note:

Cyper : Cypermethrin.

Chloran : Chlorantraniliprole.

COM-Bt : Commercial B. thuringiensis.

M. anisopliae : Metarhizium anisopliae.

researchers. Basri et al. (1991) evaluated four different products and found that B. thuringiensis, cyfluthrin and diflubenzuron were more effective than endosulfan. In our study conducted at Site 1 , the products of $B$. thuringiensis gave equally satisfactory control level as cypermethrin and chlorantraniliprole only up to 34 DAFT. Afterwards, the population of bunch moth in plots treated with both $B t$ products increased to as high as control. However, in our trial at Site 2, the application of $B$. thuringiensis was able to reduce population of bunch moth up to 49 DAFT. Comparison study between $B$. thuringiensis and cypermethrin done by $\operatorname{Lim}$ (2012) also reported that the $B t$ product was more effective than cypermethrin. Continuous spraying of $B t$ at rate of $1 \mathrm{~g}$ litre $^{-1}$ for six rounds at the interval of 15 days has reduced infestation from more than $50 \%$ to less than 15\%. Therefore, another round of application is required after 49 days, once the population is detected to be above the threshold level.

Based on findings at the study Site 1, the use of chlorantraniliprole to control bunch moth was more effective than other products. The application 
of chlorantraniliprole have drastically reduced the population of bunch moth and the control effects seemed to be longer, up to 59 days after the last spraying. Spraying of product at $8 \mathrm{ml}$ per 16 litres water, and applied at 1 litre per palm, was found to be able in reducing the bunch moth infestation to below the threshold level of less than 5 LPS as early as 7 DAFT. The population of larvae in plots treated with this chemical was then maintained at low levels for more than 50 days after the last spraying. This information is important as it highlights the longer effects of chlorantraniliprole in the field and thus prolongs the spraying interval between each application round. The effects of chlorantraniliprole application on other beneficial organisms such as predators and parasitoids are well documented. It was reported that the application of chlorantraniliprole was able to reduce lepidopteran pests of soyabean, without affecting the populations of predators (Whalen et al., 2016). Another study by Fernandes et al. (2016) also reported that chlorantraniliprole showed lowest toxicity and sub-lethal effects to beneficial insects compared to acephate, bifenthrin, chlorpyrifos, deltamethrin, imidacloprid and thiamethoxam. However, more information on the effects of chlorantraniliprole in oil palm pollinating weevil, E. kamerunicus is required.

Study by Basri et al. (1991) showed that by practicing sanitation technique alone was not sufficient to reduce the bunch moth population. Implementation of IPM by combining sanitation technique with the spraying of products such as $B$. thuringiensis has proved to reduce the bunch damage (Lim, 2012). To further improve the sanitation techniques, removal of rotten or badly infested post-anthesis male inflorescences may be necessary, as these materials were found favourable breeding sites of the early stages of bunch moth. However, it must be done cautiously as excessive removal of male inflorescences can adversely affects the population of oil palm pollinating weevil, $E$. kamerunicus. Population census of bunch moth larvae should also be conducted regularly so that once the population is detected to be above the threshold, spraying of $B$. thuringiensis can be conducted to bring the larval population level down.

\section{CONCLUSION}

This study showed that the highest number of early instars of T. rufivena was found on post-anthesis male inflorescence, while later stages of instar and pupae were mostly found on female inflorescences and developing bunches. The trial in Site 2 found that biological products such as B. thuringiensis, $M$. anisopliae and chemicals such as cypermethrin and chlorantraniliprole were effective to control bunch moth up to 34 and 49 DAFT. Application of biological product is recommended as the products are safer to non-target organisms, particularly the oil palm pollinating weevil, E. kamerunicus. As chlorantraniliprole has longer effects in reducing bunch moth population which is up to more than 50 days after the last spraying, this chemical could be applied at longer interval of more than 14 days between each round. This approach will give ample time for the beneficial organisms especially the oil palm pollinating weevil, predators and parasitoids to re-establish in the population. Alternate application of biological agent products such as $B$. thuringiensis with chlorantraniliprole may provide the best control method of oil palm bunch moth larvae, without negatively affecting the population of pollinators, predators and parasitoids. It is suggested that studies on management aspects also need to be carried out such as incorporating sanitation practices with insecticide application, mass trapping of adult moths and ecological aspects of the pest. Findings of these studies can provide an insight to develop tool for a more effective control of bunch moth in future.

\section{ACKNOWLEDGEMENT}

The authors would like to extend their gratitude to the Director-General of MPOB for permission to publish this article. We would also like to thank the staff of the Entomology and Ecological Research Group, Applied Entomology and Microbiology Unit of MPOB Research Station Lahad Datu, Sabah and MPOB Sessang, Sarawak. Our appreciation also goes to the staff of Research and Development (R\&D) Department, Ta Ann Pelita Igan Plantation Sdn Bhd and Sarawak Oil Palm Berhad, as well as the management of both the estates and workers who assisted us in this study.

\section{REFERENCES}

ALOUW, J C; MORALLO-REJESUS, B and OCAMPO, V R (2005). Biology of the coconut spike moth, Tirathaba fructivora (Meyr.) (Lepidoptera: Pyralidae). Philippines Entomologist, 19(1): 84-93.

BASRI, M W; MUKESH, $\mathrm{S}$ and NORMAN, K (1991). Field evaluation of insecticides and cultural practice against the bunch moth, Tirathaba rufivena (Lepidoptera: Pyralidae) in a mature oil palm plantation. Elaies, 3(2): 355 -362.

BASRI, M W and NORMAN, K (2000). Insect pests, pollinators and barn owl. Advances in Oil Palm Research (Yusof, B; Chan, K W and Jalani, B S eds.). MPOB, Bangi. 466-541. 
FERNANDES, M E S; ALVES, F M; PEREIRA, R C; AQUINO, L A; FERNANDES, F L and ZANUNCIO, J C (2016). Lethal and sublethal effects of seven insecticides on three beneficial insects in laboratory assays and field trials. Chemosphere, 156(2016): 45-55.

GODFRAY, H C J (1985). Mass rearing the Tachinid fly Argyrophylax basifulva a parasitoid of the greater coconut spike moth (Tirathaba spp.) (Lep: Pyralidae). Entomophaga, 30(3): 211-215.

IDRUS, M S; ABU HASSAN, A; ABDUL HAFIZ, A M and AIMAN, H J (2016). Fruit bunch moth Tirathaba sp. (Lepidoptera: Pyralidae) infestation in oil palm planted on peat soil: biology and ecology. Proc. of the Second Entomology Postgraduate Symposium (ENTOPOST 2016). 29-30 March 2016. Bangi, Selangor, Malaysia.

ISMAIL, B S; MASLINDA, $M$ and ZURIATI, Z (2012). Effects of temperature, soil moisture content and soil type on the degradation of cypermethrin in two types of Malaysian agricultural soils. World Applied Sciences J., 17(4): 428-432.

KHOO, K C; PETER, A C O and HO, C T (1991). Crop Pest Management in Malaysia. Tropical Press Sdn Bhd, Kuala Lumpur. p. 242.

KUMAR, R; TIAN, J C; NARANJO, S E and SHELTON, A M (2014). Effects of Bt cotton on Thrips tabaci (Thysanoptera: Thriptidae) and its predator, Orius insidiosus (Hemiptera: Anthocoridae). J. Economic Entomology, 107(3): 927-932.

LIM, K H (2012). Integrated pest management of Tirathaba bunch moth on oil palm planted on peat. The Planter, 88(1031): 97-104.

LOPEZ, J A; ELDRIDGE, J R; ZOMMICK, D H; PRASETYO, A E and SUSANTO, A (2016). Longterm study of Bacillus thuringiensis SC (Strain ABTS351) towards Tirathaba rufivena Walker and the effect to Elaeidobius kamerunicus Faust, insect biodiversity and oil palm productivity. Proc. of the Sixth IOPRIMPOB International Seminar; Current Research and Management of Pests, Ganoderma and Pollination in Oil Palm for Higher Productivity. 27-29 September 2016 Medan, Indonesia.

MOORE, D (2001). Insects of palm flowers and fruits. Insects on Palms (Howard, F W; Moore, D; GiblinDavis, R M and Abad, R G eds.). CABI Publishing, Wallingford, Oxon, UK. p. 233-266.

MPOB (2016). Survey on fruit set, pollinating weevil, major pests and its managements in oil palm plantations. Unpublished presentation. MPOB, Bangi.
NAJIB, A; SITI RAMLAH, A A; MAZMIRA, M M and BASRI, M W (2009). Effect of Bacillus thuringiensis, Terakil- ${ }^{\circledR}$ and Teracon- $\mathrm{a}^{\circledR}$ against oil palm pollinator, Elaiedobius kamerunicus and beneficial insects associated with Cassia cobanensis. J. Oil Palm Res. Vol. 21: 667-674.

RAMLE, M; BASRI, M W; NORMAN, K; SITI RAMLAH, A A and NOOR HISHYAM, H (2006). Research into the commercialization of Metarhizium anisopliae (Hyphomycetes) for biocontrol of oil palm rhinoceros beetle, Oryctes rhinoceros (Scarabaeidae), in oil palm. J. Oil Palm Res. (Special Issue April 2006): $37-49$.

SALAMA, H S and ZAKI, F N (1984). Impact of Bacillus thuringiensis Berl. on the predator complex of Spodoptera littoralis (Boisd.) in cotton field. J. Applied Entomology, 97(1-5): 485 - 490. DOI: 10.1111/ j.1439-0418.1984.tb03779.x

SITI RAMLAH, A A; NAJIB, A; MAZMIRA, M M and BASRI, M W (2012). Field efficacy of MPOB Ecobac-1 (EC) for controlling bagworm, Pteroma pendula (Lepidoptera: Psychidae) outbreak in oil palm plantation. Proc. of the $11^{\text {th }}$ UMT International Annual Symposium on Sustainability Science and Management, Terengganu, Malaysia. 9-11 July 2012.

SUSANTO, A; SUDHARTO and PERDANA ROZZIANSHA, T A (2011). Penggerek tandan kelapa sawit, Tirathaba rufivena Walker. Informasi Organisme Pengganggu Tanaman, H (0004). Pusat Penelitian Kelapa Sawit, Medan.

VALENT BIOSCIENCES CORPORATION (2014). Dipel: The world's leading biological insecticide. https: / / cropprotection.valentbiosciences.com / valent-biosciences-corporation-biorational-cropprotection/insecticides/products/dipel, accessed on 11 November 2016.

WHALEN, R A; HERBERT, D A; MALONE, S; KUHAR, T P; BREWSTER, C C and REISIG, D D (2016). Effects of diamide insecticides on predators on soybean. J. Economic Entomology (August): 1-6.

WOOD, B J and NG, K Y (1974). Studies on the biology and control of the oil palm bunch moth Tirathaba rufivena (Walker) (Lepidoptera: Pyralidae). Malaya Agriculture J., 49: 301-331.

YAAKOP, S and SHAFARIZA, M A M (2015). The bunch moth of the Tirathaba species as hidden pest on the peat soil of oil palm plantations: implications of biological life cycles, the DNA barcoding approach, and infestation pattern detection. Proc. of the $3^{\text {rd }}$ International Conference on Chemical, 
Agricultural and Medical Sciences (CAMS-2015). 10-11 December 2015. Singapore.

ZELAZNY, B (1985). Susceptibility of two coconut pests, Oryctes rhinoceros (Col.: Scarabaeidae) and Tirathaba rufivena (Lep.: Pyralidae) to the entomoparasitic nematode Steinernema feltiae (=Neoaplleactana carpocapsae). Entomophaga, 30(2): 121-124.

ZULKEFLI, M; NORMAN, K; RAMLE, $\mathrm{M}$ and BASRI, M W (2012). Integrated pest management of termite and bunch moth in oil palm planted on peat in Malaysia. Proc. of the Fourth MPOB-
IOPRI International Seminar: Existing and Emerging Pests and Diseases of Oil Palm Advances in Research and Management. 13 December 2011. Bandung, Indonesia.

ZULKEFLI, M; ALINDRA, G S; SAHARUL, A M; NORMAN, K; SITI RAMLAH, A A; SIAW, T C; RAMLE, M and SITI NURULHIDAYAH, A (2015). Evaluation of chemical insecticides and biological agents to control bunch moth, Tirathaba rufivena in young oil palm area in Sarawak, Malaysia. Proc. of the PIPOC 2015 International Palm Oil Congress and Exhibition: Oil Palm: Powering the World, Sustaining the Future. 6-8 October 2015. Kuala Lumpur, Malaysia. 